The Journal of Society and Media, April 2021, Vol. 5(1) 218-238

https://journal.unesa.ac.id/index.php/jsm/index

E-ISSN 2580-1341 and P-ISSN 2721-0383

Accredited KEMENRISTEK/BRIN No.148/M/KPT/2020

DOI: 10.26740/jsm.v5n1.p218-238

\title{
Implementation of the Policy for Capacity Building of Village Apparatus in Merangin Regency, Jambi
}

\author{
Pahrudin $\mathrm{HM}^{1^{*}}$, Burlian Senjaya ${ }^{2}$ \\ ${ }^{1,2}$ Faculty of Social and Political Sciences, Universitas Nurdin Hamzah Jambi, Jl. Kol. \\ Abunjani, Sipin, Telanaipura, \\ Kota Jambi, Indonesia \\ Email: pahrudinhm9@gmail.com \\ Email: senjayaburlian@gmail.com
}

\begin{abstract}
This study is intended to analyze the implementation of policies carried out by the Merangin Regency Government of Jambi Province in order to increase the capacity of village apparatus. This study used Weimer and Vining's policy implementation, which consists of policy logic, policy environment and implementor capability. This research was conducted using a qualitative approach with a type of case study. Data collection was carried out by interviewing 11 respondents and reviewing data related to the research topic. After collected, the data were analyzed by data reduction, data presentation, and drawing conclusions. Based on this research, it is known that in terms of policy logic, the Merangin Regency Government really understands the significance of the existence of village officials in managing existing resources, so it does Workshop on the Implementation of SISKEUDES and Provision of Village Technical Capacity Development (P2KTD) was held. The policy environment also supports the implementation of this policy through commitments conveyed by the Head of Regency, Head of the Merangin Regency Village Community Development Agency (PMD) and Heads of Sub-Districts. The ability of implementors consisting of village officials is still very limited in applying training materials in accordance with the potential context of their respective villages.
\end{abstract}

Keywords: policy implementation, village, apparatus, capacity

Paper type: Research paper

*Corresponding author: pahrudinhm9@gmail.com

Submited: 2021-01-21 ; Accepted: 2021-04-29 ; Published: 2021-04-30

Cite this document: HM, Pahrudin, and Burlian Senjaya. (2021). Implementation Of The Policy For Capacity Building Of Village Apparatus In Merangin Regency, Jambi. The Journal of Society and Media, 4(2), 218-238. DOI: 10.26740/jsm.v4n2.p218-238. 
MH Pahrudin: Implementation Of The

Policy For Capacity Building Of Village

Apparatus In Merangin Regency, Jambi

219

\section{INTRODUCTION}

The study of the capacity of village apparatus is very interesting and important to do. This is related to the importance of the ability possessed by village apparatus in managing a community and region. As it is known that the Indonesian Village Law Number 6 of 2014 further confirms the importance of focusing villages on development in Indonesia. This is related to Indonesian Central Statistics Agency (Badan Pusat Statistik 2020) data that the village is home to the majority of Indonesian people and is home to most of the country's natural resources. Besides that, the Indonesia village is the smallest region that has the government equipment recognized in the political system adopted by Indonesia.

The various characteristics above make the village always a concern of the government which was realized in the birth of various laws and rules; the latest is Law Number 6 Year 2014. These regulations were raised as a form of government attention to the village, while also intended to address the problems that arose in them. This latest village regulation manifests itself in the form of self-governing community and local self-government in the form of delegation of authority covering the affairs of village administration, implementation of village development, community development, and empowerment of rural communities (Wahyudi et al. 2016). According to Nikmatul Huda (Hartati, HM, dan Rahmi 2020), village regulation in the form of various regulations is aimed at addressing issues surrounding the position of indigenous people, democratization, diversity, community participation, progress and equitable development, poverty and socio-cultural conditions that can disrupt the integrity of the nation.

Administratively, Law Village Number 6 Year 2014 is indeed better than previous similar regulations. It's just that, attention to the village should not only stop the publication of regulations like this, but the implications in the future must also be considered. The objective of the village regulation closely related to the quality of human resources which are the motor of village management, especially related to village officials. Human resources are acute 
problems of the village because their quality is still low, not only related to the community in general, but also village officials or village government (Asrori 2014). The study by (Anto dan Amir 2017), (Sahi 2018), (Syaifullah 2017), (Brillo 2017), (Kisman dan Tasar 2014), (Nak-ai et al. 2018), (Sharma 2015), (Wikowski dan Kiba-Janiak 2014), and (Nugroho 2014) also revealed that the quality of village apparatus is still not optimal or is still very necessary to be improved and the ability, willingness and potential of the village apparatus as well impacts and approaches to governance and implementation development has not been maximized because the capacity of human resources is still limited. This phenomenon is of course closely related to other problems inherent in the domicile of the largest part of the Indonesian people, namely poverty, unemployment, education and health (Hartati et al. 2020).

On this basis, there needs to be an effort to overcome the problem of limited human resources in the village to achieve the objectives of village regulation as contained in Law Number 6 Year 2014 about Village. Based on political perspective, the effort is called public policy that Thomas R. Dye (HM 2020) said what is done or not done by the government to overcome the problems faced by its people. Meanwhile, Herald Laswell and Abraham Kaplan (HM 2019) define public policy as a program that is structured with a set of objectives, values, and certain practices. On the other hand, Steven A. Peterson (HM 2020) defines public policy simply by considering it as an action taken by the government to overcome various problems. This effort also seems to be in line with Muhammad Fadli (Hartati et al. 2020) who stated that village management must pay attention to how the village apparatus adapted to the capacity needed to manage this important area in the modern world.

Public policy studies recognize several stages, namely policy formulation, policy implementation and policy evaluation (HM 2020). Policy formulation is a very important initial stage because it presents information to analysts. The formulation of policies contains plans that will be carried out to overcome social problems, their goals and priorities, policy alternatives, and the advantages and disadvantages of each policy. Furthermore, policy implementation is interpreted as a method used so that a formulated and defined public policy can be implemented and achieve the desired goals (HM 
MH Pahrudin: Implementation of The

Policy For Capacity Building Of Village

Apparatus In Merangin Regency, Jambi

221

2020). Meanwhile, policy evaluation is intended to assess the effectiveness of a public policy so that it can be held accountable to the public (HM 2020).

Therefore, efforts to increase the capacity of village officials are being carried out, it is interesting to see how it is implemented. As the main manager of village resources, the village apparatus absolutely has good capacity. According to Marilee S. Grindle (Mirnawati 2019) (, capacity in terms of the ability to perform appropriate tasks effectively, efficiently, and sustainably. However, not always policies to solve problems can be implemented and achieve the expected goals. Policy makers are not guaranteed to be successful in implementation. There are many variables that influence the success of policy implementation, both individually and in groups or institutions. The implementation of a program involves the efforts of policy makers to influence the behavior of implementing bureaucrats so that they are willing to provide services and regulate group behavior target.

In this regard, several parties have tried to present views about the factors that are considered to be able to influence the implementation of a public policy. Some of these experts include Grindle, van Meter and van Horn, Edward III, Mazmanian and Sabatier, and Weimer and (HM 2020). In the context of this study, the concept of policy implementation from Weimer and Vining which consists of (1) policy logic, (2) the environment in which the policy is operated, (3) the ability of policy implementers will be used. Through this study, we shall know the implementation of the policy to increase the capacity of village apparatus in Merangin Regency. This research also strengthens the findings of previous studies on the importance of government policies, especially local government in increasing the capacity of village apparatus. This is important to do, so that village apparatus have the ability to manage the resources their regions have as an effort to improve community welfare, especially after the enactment Law No. 6/2014. 


\section{METHOD}

This study used a qualitative research approach, that according to (Creswell 2007) is an approach that gives an opportunity for researchers to be able to carry out detailed descriptions and interpretations in order to gain a holistic understanding. This type of research is a case study, which is understood by (Creswell 2007) as a type of research that can be interpreted as an approach to study, explain, or interpret a case in its natural context without outside intervention. More specifically, this research is an instrumental case study which is used to examine a particular case so that a perspective can be presented on the issue or improvement of a theory.

This study was conducted in Merangin Regency, Jambi Province, the largest region in Jambi Province $\left(7,679 \mathrm{~km}^{2}\right)$, especially in Rantau Limau Manis Village and Limbur Merangin Village. Merangin Regency has a variety of potential natural resources that are suitable for the orientation of regional development. Merangin Regency has 4 superior commodities which are the backbone of the population's economy in one of the western districts of Jambi Province, namely rubber, oil palm, coffee, and coconut (HM 2017; Halim, HM 2020). Based on BPS data (2020), the area of rubber in Merangin Regency was 132,192 hectares, oil palm covering 53,792 hectares, robusta coffee with an area of 10,860 hectares, and coconut with an area of 1,658 hectares. All of the above resources are important capital to improve people's welfare through good management by the village apparatus.

As required in qualitative research using the case study method, the data is collected from several sources, namely through documents and archive records, interviews, direct observation, (participant observation) and other physical devices related to village apparatus in Merangin Regency (Creswell 2007). This research data is qualitative and consists of primary data and secondary data. Most of the primary data was collected through interviews, direct observation, and participant observation, while a small portion of other data was obtained from documents and physical devices related to the village apparatus of Merangin Regency.

Interviews were conducted to explore the experiences of ten informants and their subjective interpretations of village apparatus and policy of Merangin Regency. The determination of the ten informants is based on their involvement 
MH Pahrudin: Implementation Of The

Policy For Capacity Building Of Village

Apparatus In Merangin Regency, Jambi

223

with the phenomenon that is the topic of research. The informants were chosen and classified into two sections, namely (1) Village apparatus of 8 persons in Rantau Limau Manis Village and Limbur Merangin Village, and (2) Merangin Regency Government of 3 persons (The Regent and 2 District Leaders). The interview is based on an interview guide. However, researchers always develop questions in various directions in accordance with the development of informant responses in order to obtain complete, in-depth, and accurate information. In this case, each interview is directed to a topic that in the view of the researcher is the competency of the relevant informant in accordance with their respective status, without neglecting the extraction of general information. The researcher records all the dialogue that takes place during the interview, and makes additional notes as needed. The recording is then converted into an interview transcript which is done after the interview is conducted.

Creswell (2007) revealed that effort to analyze data can use qualitative data analysis techniques in three ways, namely data reduction, data presentation (displaying data), and drawing conclusions. Data reduction is the process of selecting, focusing on simplifying, abstracting, and transforming "rough" data that arise from written records in the field. Furthermore, the presentation of data is a collection of information that has been organized to facilitate the possibility of drawing conclusions and taking action. The final method used is drawing conclusions or verification, namely interpretation of the entire data collected so that adequate conclusions can be obtained.

\section{RESULT AND DISCUSSION}

Village and Apparatus in Indonesia. Based on (Badan Pusat Statistik 2020), throughout Indonesia there are 75.436 villages and Jambi Province has 1.399 villages with various categories. The diversity of these village categories is based on the Village Development Index (IPD) level which is based on five dimensions, namely Basic Service Dimensions, Infrastructure Condition Dimensions, Transportation Dimensions, Public Service Dimensions, and 
Village Government Implementation Dimensions. As a result, the existence of villages in Indonesia emerged in three categories, namely villages with underdeveloped status as many as 14.461 villages (19.17\%), developing villages as many as 55.369 villages $(73.40 \%)$, and independent villages with 5.606 villages (7.43\%).

Based on data in 2019, all dimensions of IPD increased when compared to 2014, the highest increase (9,81 points) existed in the Implementation of Village Government dimensions, while the smallest increase occurred in the Basic Services dimension (0,92 points). While in Jambi Province, only 102 villages $(7.29 \%)$ were independently categorized, while the rest were underdevelopment 69 villages (4.93\%) and developed 1,228 villages (87.78\%) from a total of 1,399 villages. Although a small number of villages are categorized as Independent Villages, the number of villages is increased by 72 villages compared to 2014. Meanwhile, the Village is underdevelopment reduced by 123 villages.

Meanwhile, other data that is also closely related to the village is the problem of poverty and unemployment. Based on BPS data (September 2020), Indonesia's poverty rate is still in the range of $9.66 \%$ (25.67 million people) where as many as 15.54 million of these are domiciled in the village, while in Merangin Regency is $9.43 \%$ (35.48 peoples). The unemployment rate in Indonesia based on BPS data (2020) is also still quite large (5.01\%), while in Merangin Regency is 4.000 people, most of which are those living in rural areas.

In addition to the three problems above, another problem that is also inherent in the village is related to the quality of the village apparatus which is still unable to meet the required standards. This is as raised in studies conducted by (Anto dan Amir 2017), (Sahi 2018), (Syaifullah 2017), (Brillo 2017), (Kisman dan Tasar 2014), (Nak-ai et al. 2018), (Sharma 2015), (Wikowski dan Kiba-Janiak 2014), and (Nugroho 2014) which states that the quality of village apparatus is still low. This finding is in line with Suwardjo's (Hartati et al. 2020) summary which mentions that there are various problems faced by village government in carrying out its duties, namely limitations of staff or employees both in quality and quantity that affects the implementation of government village; quality and quantity of assistance, training and monitoring village development is low so that it affects the effectiveness and efficiency of program 
MH Pahrudin: Implementation Of The

Policy For Capacity Building Of Village

Apparatus In Merangin Regency, Jambi

225

interventions; village isolation which results in lack of community accessibility towards public service centers; low welfare of the village related to the provision of basic services and village economic development; the quality and competence of village human resources is still low and limited; the position of the dominant local figure is still a reference in policy making both cultural and formal causing the role of the village government system to be dominated by the spirit of feudalism and clientelism. In the same context, Garvera (2018) also states that public services by the government are highly increasing and the quality must be improved. Further consequences of this demand require the government to provide officers with high dedication and discipline as well as loyalty to full service to the tasks that are their responsibility and oriented to community service as public servants.

Meanwhile, according to Shakinah (2019), the low performance of village officials is influenced by several factors including:1). Age as a unit of time that measures the existence of an object or creature, both living and dead. 2). Lack of motivation is an impulse that causes someone to do an action to achieve the goal. While what happens in the field, the motivation given can be said to be very lacking that makes the village apparatus less eager to learn new things, such as the use of computers and websites that should be used by all village officials. 3). Lack of training and development as a process designed to improve technical knowledge and skills, or improve employee performance. Development is the process of increasing conceptual ability, ability to make decisions and human relations. Therefore, to create work effectiveness, the village head should conduct a training and development program. It is intended that the village apparatus can complete their duties effectively and efficiently, without interfering with other work. 4). Consultation as the success of an organization in realizing its objectives is through several supporting factors. The skills and knowledge possessed by the members of the organization very clearly will lead the organization to achieve the goals set. Besides that, one of the factors needed to achieve the goal is consultation, to assess the consultation process carried out through several indicators, namely by providing input, receiving complaints and giving a good explanation of what the apparatus 
complained of. 5). Facilities as one of the success factors in supporting community service is adequate to do a job. This applies in every service carried out by the government and private parties. Without supporting facilities, whether in development, government or community empowerment, it will not be said to be successful if the facilities provided are very lacking. Facilities provided such as the provision of supporting facilities and the provision of supervisors. The provision of this facility is intended for the village apparatus to complete the work properly, on time and not interfere with other work, which in turn will hamper further work.

Several regions in Indonesia have and are currently carrying out several programs aimed at increasing the capacity of village officials, one of them is The Government of West Kalimantan Province. On the basis of the desire that the village apparatus as the spearhead of development have a good ability in managing its territory, The Government of West Kalimantan Province held a series of activities funded through the Provincial Budget Number 046/BPMPD/2015 August 2, 2015 (Ismiyarto 2016). This program was attended by village heads, village secretaries and other village apparatus under the coordination of the Village Government Office (PMD) in the West Kalimantan Province. This village apparatus training program initiated by the provincial government has greatly contributed to the increased ability of the village government to manage its territory in West Kalimantan Province. This positive impact certainly occurs because of right method implementation training then the subject matter will be carried optimally and will be more useful towards the capabilities of village apparatus. The training technique has been used participatory learning methods of training; it is expected the presence of the communication between the two sides and the village teachers trained. The type of this method is speech, interview, brainstorming, discussion groups, plenary discussions, panel discussions, demonstration, practicing, work individual simulation, workgroup, and suggestions for a jarring experience. This type is important because the village apparatus is the largest human and natural resource manager in Indonesia, so that they are required to have good managerial skills.

Based on the data above, villages that are home to the majority of the population of this country still face various problems, without exception at 
MH Pahrudin: Implementation Of The

Policy For Capacity Building Of Village

Apparatus In Merangin Regency, Jambi

227

Merangin Regency and Jambi Province generally. From the government side, it can be said that only a small proportion of villages (7.43\% and $7.29 \%)$ in Indonesia and Jambi Province have achieved the main objectives of their regulation, namely the realization of independent villages. Not to mention if it is associated with the problem of poverty, unemployment which is still closely attached to the villagers, and village apparatus quality that is still low.

Merangin Regency is one of the districts in Jambi Province and geographically bordering the Bungo Regency in the north, Sarolangun Regency in the east, Lebong Regency in the south, and Kerinci Regency in the west. Overall, the area of Merangin Regency is $7,679 \mathrm{~km}^{2}$ consisting of 24 subdistricts and 372,205 inhabitants. As the largest region in Jambi Province, Merangin Regency has a variety of potential natural resources that are suitable for the orientation of regional development. Merangin Regency has 4 superior commodities which are the backbone of the population's economy in one of the western regencies of Jambi Province, namely rubber, oil palm, coffee, and coconut. Based on Badan Pusat Statistik (2020), the area of rubber in Merangin Regency was 132,192 hectares, oil palm covering 53,792 hectares, robusta coffee with an area of 10,860 hectares and coconut with an area of 1,658 hectares.

As the party entrusted with the resposibilities of managing the area, the Merangin Regency government should be able to use its local potential as a basis for regional development. This is in line with the concept of local potential-based development which relies on the understanding that real development comes from within (local government and society). Areas that have certain potentials (natural resources and human resources) can apply development models that are in accordance with their characteristics. The hope, by relying on sources originating from within the region, then everyone feels the ownership and development goals in the form of welfare will be achieved well.

Related to this, based on BPS Merangin data (2020), there were 101,866 people working in the agricultural sector (mainly rubber, oil palm, coconut and coffee) with 36,905 heads of families (KK). That is, by focusing development 
on these three main commodities, Merangin Regency Government has helped the lives of most of its population. In this way, the level of welfare of the people of Merangin Regency will also increase because the main source has been well managed by the local government as the main controller at the regional level. This is in line with James Midgley (HM 2020) stating that there are three categories of achievement regarding welfare, namely regulation of social problems, fulfillment of needs and the acquisition of opportunities to improve living standards. This method can be carried out jointly by the family, community and society at large, including local government.

Regulatory, the efforts to overcome these village problems have been the focus of the government, both through village law and related ministerial policies. Law No. 4 of 2016 is the main legal basis for village management and is a reference for other village-related policies. Technical management of village management is included in Minister of Village, Regional Development Disadvantaged, and Transmigration of the Republic of Indonesia Number 2 Year 2016 Article 1 Paragraph 11 Regarding the Village Build Index which mentions that the independent village, or can be called the Sembada village is advanced villages that have the ability to carry out development village to increase the quality of life and life as much as possible welfare of village communities with social security, economic resilience, and sustainable ecological resilience. A village can be said to be an independent village if it has ownership of three indices in it, which are the index of social security, resilience economy and ecological resilience.

The main point of this minister regulation requires the availability of quality village officials. This is important because the village apparatus is the backbone of village management with a line of capital it has. There are several areas of authority, according to Article 18 of Law No.6/2014, which was given to villages, namely organizing village government; implementation of village development; village community development; and empowering village communities. Then the authority of the village, based on Article 19 of Law No.6/2014 includes four things, namely authority based on origin rights; village-scale local authority; authority assigned by the Government, Regional Government Province, or Regency/City Government; and other authorities assigned by the Government, Government Provincial Region, or Regency/City 
MH Pahrudin: Implementation of The

Policy For Capacity Building Of Village

Apparatus In Merangin Regency, Jambi

229

Government in accordance with the provisions of the legislation. Furthermore, carrying out the authority is based on community initiative, original rights, and customs. With the issuance of the law provides space for village government and community in the village to regulate and manage the potential of village more broadly to achieve the vision. This can be seen in Article 20 and Article 21 that the implementation of the authority is regulated and administered by the village. This will at once a challenge for the village whether this approach can solve the problems faced by the village so far.

The village authority was then described in the Minister of Home Affair regulation No. 44/2016 concerning Village Authority. More than that, in terms of the budget, based on Article 72 of the Law the village allows to get funds from various sources for carrying out the authority it has. The sources including village original income, State budget (APBN) allocation through village-based government programs, part of the results of district tax and retribution/the municipality for $10 \%$, the allocation of village funds is part of the balancing funds received by the district/city at least $10 \%$ after deducting special allocation funds, financial assistance from Provincial and district/city budget (APBD), grants and donations as well other possible funds. With the issuance of the Village Law, a shift occurred in approaches from village authorities that are targeted, as well in the previous legislation, to authority mandate village. In addition, the position of the village becomes community governance which is a combination of self-governing community and local self-government based on principles of recognition and subsidiarity as the main principle besides the other principles. New approaches and funds allocated to villages will be a challenge for the village to solve various problems have faced so far. The three main actors have an important role in implementing village authority which includes Village Government (Village Head and Village Equipment), Village Consultation Agency (BPD), and village communities.

Though efforts to achieve a prosperous society require the implementation of good governance continuously through an element of professionalism from government officials in carrying out government duties. Therefore, there needs to be a breakthrough effort that can lead villages in 
Indonesia to become independent villages through increasing the capacity possessed by their apparatus. Efforts to increase the capacity of village officials are very important to do, not only related to the amount of village funds that they have to manage (an average of IDR. 1.4 billion), but also regarding the large resources (natural and human) owned by the village. That is, the village already has a lot of capital to realize the aspirations of its citizens, welfare. It starts from natural resources and human resources to regulation through Village Law No. 6 Year 2014.

The efforts to improve the quality of village officials in Indonesia within the framework of politics known as policy that is interpreted as an action taken by the government to overcome various problems (HM 2020; Rosawaningsih 2018). Policies are essential decisions that directly regulate the management and distribution of natural, financial, and human resources in the public interest (HM 2020); (Kurnia dan Widhiasthini 2021). Public policy refers to a term or concept to explain very specific action options, such as in certain fields in public facilities sectors. Based on this second perspective, efforts to overcome the problem of low quality of village apparatus in carrying out management functions can be conducted in various forms. One of them can be done by optimizing the National Framework for Developing and Enhancing Government Capacity in Order to Support Decentralization, Policy of the Minister of Home Affairs and Head of National Development Planning Agency (Bappenas) 2002. In this guide it is stated that the development and improvement of capacity include three levels, namely 1) System level, which is regulatory framework and policies that support or limit the achievement of certain policy objectives; 2) Institutional or entity level, namely organizational structure, decision-making processes within the organization, work procedures and mechanisms, management instruments, relationships and networks between organizations, etc.; 3) Individual-level, namely the level of skill, qualification, knowledge/insight, attitude, ethics and motivation of individuals working in an organization.

According to Wahyudi's record (Hartati et al. 2020), the optimization of the government's capacity-building mechanism has proven to be able to improve the ability of village officials to carry out their functions. Village apparatuses who follow the stages of capacity building are provided with 
MH Pahrudin: Implementation of The

Policy For Capacity Building Of Village

Apparatus In Merangin Regency, Jambi

231

knowledge about village management from planning, implementation, to evaluation. The same thing was also expressed by (Nugroho 2014) who said that the participation of village officials in capacity building training enabled them to understand aspects surrounding village management, such as administration and planning and activity reports. Along with the increasingly complex problems that exist in the village, the development of the capacity of the village apparatus is certainly not just about administrative aspects. Moreover, village officials are required to have knowledge and capabilities of public services, asset management, finance and regulatory socialization. This is certainly related to several aspects listed in Law Number 6 of 2014 about Village as the most recent reference in village management. This means that efforts to overcome the problem of the quality of village apparatus which are still low in a legal political perspective are carried out by strengthening the training content by including material on village budget preparation, village funds (DD) management, village wealth management, and village-owned business entity (BUMDes) management.

The effort to increase the capacity of the village apparatus is one of the priorities of the Government of Merangin Regency program, especially in the time of The Regent of Al Haris who is now undergoing a second period of his leadership. This can be seen in the big vision carried out by The Government of Merangin Regency, which wants the largest region in the Jambi Province to be superior in the Agriculture and Tourism Sector. At first glance, this vision does not correlate directly with efforts to increase the capacity of village officials reflected in the latest village regulations in Indonesia. However, if it is considered further, it can be seen that this vision will be realized if superior resources in agriculture and tourism are managed properly. Management of these agricultural and tourism resources can only be carried out by the village apparatus because their existence is in the village. Therefore, good management capability is an element that the village apparatus absolutely must have to realize the big vision of Merangin Regency.

Efforts to improve the capacity of village officials in Merangin Regency are carried out in various forms of activities, both those related to 
central and provincial government programs, as well as districts. The activities carried out by The Government of Merangin District through the Village Community Empowerment Service are a Workshop on Village Financial Management Systems with the SISKEUDES (Sistem Keuangan Desa) Application and P2KTD (Penyedia Peningkatan Kapasitas Teknis Desa/ the Provision of Village Technical Capacity Building). These activities were attended by all apparatus in 205 villages throughout Merangin Regency, specifically the village head and village secretary. These programs are intended to assist village officials at Merangin Regency in conducting village management, from administration to finance at the stage of budgeting, administration, reporting, to accountability. Through apparatus that have good village management capabilities, various village resources can be used to improve the welfare of the community in Merangin Regency.

Efforts to improve the capacity of village officials carried out by The Government of Merangin Regency are indeed not directly related to the welfare of the community. However, as is well known, Merangin is one of the regencies that has the largest potential natural resources in Jambi Province. This region is a place for rubber, palm oil, coffee, coconuts and so on. The majority of Merangin residents also depend on their lives on these commodities. Therefore, by having a quality village apparatus, they will be able to help the community manage these large resources. Through good management of these potential resources, the socio-economic life of the community will also improve.

Based on the concept of Bappenas, this policy is part of capacity development at the individual level. This is because those who participated in this activity were village officials who underwent training about good village management. Even though village management training has been carried out, it is certainly not easy to change existing habits. Village management in Merangin so far has only been based on the wishes of a handful of village elites, without involving the public at large. Moreover, it is related to village assets (Tanah Bengkok or village-owned land) which have been earmarked for the village head's economic resources. Whereas, good village management requires broad public participation and accountability of village work programs (Wahyudi, Ngumar, dan Suryono 2019). Since the program will disrupt the existence of the elite, it will not be easy to implement it perfectly. Therefore, for 
MH Pahrudin: Implementation of The

Policy For Capacity Building Of Village

Apparatus In Merangin Regency, Jambi

233

this program to reach its targets precisely, more comprehensive tools are needed. Good village management also requires an effective internal control system. Thus, the implementation of the training carried out by village officials will be monitored and controlled by an internal control mechanism.

Implementation of Village Apparatus Capacity Building's Policy in Merangin Regency. As previously mentioned, policy makers are not guaranteed to be successful in implementation. There are many variables that influence the success of policy implementation, both individually and in groups or institutions. The implementation of a program involves the efforts of policy makers to influence the behavior of implementing bureaucrats so that they are willing to provide services and regulate group behavior target.

In this regard, several parties have tried to present views about the factors that are considered to be able to influence the implementation of a public policy. Some of these experts include Grindle, van Meter and van Horn, Edward III, Mazmanian and Sabatier, and Weimer and Vining. In the context of this study, the concept of policy implementation from Weimer and Vining (HM 2020) which consists of (1) policy logic, (2) the environment in which the policy is operated, (3) the ability of policy implementers will be used.

Policy Logic. In an effort to assist in the analysis of policy implementation, Weimer and Vining used policy logic. The first factor is intended so that a policy that is established makes reasonable and theoretical support. We can think of the logic of a policy as well as the logical relationship of a hypothesis.

As it is known that on the one hand, villages have a variety of resources, including the villages in Merangin regency, but on the other hand, poverty and unemployment are still high. In line with the enactment of Law Number 6 of 2014 , villages have the authority to manage their resources. The management of these resources is of course carried out by village apparatus who are elected by the community themselves with a variety of good managerial capacities. The problem is that most village apparatus still have inadequate capacity to manage a variety of potential resources to improve community welfare. Therefore, the government must assist village apparatus through policies that can increase 
their managerial capacity in managing existing resources in the village. These policies are highly dependent on the context of each area which is in line with the village's potential.

This is the logic of the policy which the Regent of Merangin, Dr. Al Haris, when asked his opinion about the efforts to increase the capacity of village officials in the area he leads. During two periods leading the largest regency in Jambi Province, Dr. Al Haris decided to continue to improve his capacity through Siskeudes Training and Provision of Village Technical Capacity Development (P2KTD). This is because according to the Merangin Regent, the introduction and deepening of material related to the financial system and managerial development is absolutely necessary so that village apparatus have the ability to manage village resources.

The environment in which the policy is operated. The environment is factor will influence the successful implementation of policy including the social, political, economic, defense, and physical or geographic. A policy can be implemented successfully in a certain area, but failed to be implemented in another area, due to different environmental conditions.

In this context, the policy of holding a Workshop on the Implementation of Sikeudes and Provision of Village Technical Capacity Development (P2KTD) for village apparatus in Merangin Regency is highly dependent on the socio-political conditions in Merangin Regency. Even though this program is a national program, of course its implementation is closely related to the regional government as the technical implementer in the field.

In relation to this, the Head of the Merangin Regency Village Community Development Agency (PMD) said that the Merangin Regency Government continues to be committed to continuing to carry out this activity. This is because there are still many village apparatus who do not understand how to manage the village and its resources. Not to mention the various regulations issued by the government regarding the existence of villages and their apparatus, especially after the existence of Law Number 6 of 2014.

The same thing was said by the Head of Tabir Ilir and West Pamenang Sub-Districts. The two sub-district heads expressed their commitment to support the government's efforts to increase the capacity of village apparatus, 
MH Pahrudin: Implementation of The

Policy For Capacity Building Of Village

Apparatus In Merangin Regency, Jambi

235

particularly through The Siskeudes Implementation Workshop Program and the Provision of Village Technical Capacity Development (P2KTD).

The problem is that not all village apparatus in Merangin Regency have the same level of understanding to be able to translate the material presented into real action in the field. This is as stated by the Rantau Limau Manis Village apparatus who stated that the materials presented in the activity were quite difficult for them to understand well. Not to mention that many village apparatus did not have adequate preparation before joining this program, such as the ability to use computers and their applications better. Apparatus of Limbur Merangin Village also admitted that, frankly, they still could not fully apply these materials in managing their village resources.

The ability of policy implementers will be used. The success of a policy can be influenced by the level of competence and skill of the policy implementers. In this context, the success of the village apparatus capacity building program really depends on the village apparatus itself. This means that the village apparatus is the determining factor whether this program is successful or not implemented and its objectives are well achieved.

As recognized by the apparatus of Rantau Limau Manis and Limbur Merangin Villages, their ability to translate training materials into real action in the field in accordance with the local context is still difficult to do. The village of Rantau Limau Manis, for example, is an area that has potential natural resources in the form of rubber and oil palm plantations. Most of the inhabitants of this village are highly dependent on the rubber and oil palm plantations that are widespread in this village and its surrounding areas. Until now, Rantau Limau Manis Village apparatus have not been able to properly implement training materials based on the local potential of this region.

Limbur Merangin Village apparatus also conveyed the same thing. Like Rantau Limau Manis Village, this village also relies heavily on rubber and oil palm plantations for its residents. Training materials related to village resource management have not been able to be translated properly by village officials in accordance with the context of the potential of the region. 
Based on above, in the future, there need to be policies that reach out to system and institutional aspects. Including regulatory framework and policies that support or limit the achievement of certain policy objectives and organizational structure, decision-making processes within the organization, work procedures and mechanisms, management instruments, relationships and networks between organizations.

\section{CONCLUSION}

As an effort to overcome the problem of the limited capacity of the village apparatus, Merangin Regency Government held policy, namely The Siskeudes Implementation Workshop Program and the Provision of Village Technical Capacity Development (P2KTD). Based on Weimer and Vining's concept, the implementation of these policies are based on policy logic and supported by a good socio-political environment by the local government through The Regency Head of Merangin, Head of the Merangin Regency Village Community Development Agency (PMD) and The District Heads. The problem lies in the implementers consisting of village apparatus who are still unable to apply training materials in the context of the potential of their respective villages.

\section{REFERENCES}

Anto, Rola Pola dan Muhammad Amir. 2017. "Competence of village apparatus in management of village funds in North Konawe Regency Indonesia." IOSR Journal of Business and Management (IOSR-JBM) 19(11):66-71.

Asrori. 2014. 'Kapasitas perangkat desa dalam penyelenggaraan pemerintahan desa di Kabupaten Kudus (Capacity of Village Devices in Organizing Village Government in Kudus District).' Jurnal Bina Praja 6(2):101-16.

Badan Pusat Statistik. 2020. Jambi dalam Angka 2020. Jambi: Author.

Brillo, Bing Baltazar C. 2017. "The politics of lake governance: Sampaloc Lake, Pandin Lake, and Tadlac Lake of the Laguna de Bay Region, Philippines." Asia-Pacific Social Science Review 17(1):66-79.

Creswell, John W. 2007. Qualitative Inquiry and Research Design: Choosing Among Five Traditions. New Delhi: Sage Publications. 
MH Pahrudin: Implementation Of The

Policy For Capacity Building Of Village

Apparatus In Merangin Regency, Jambi

237

Garvera, R. Rindu. 2018. "Kinerja Aparat Desa dalam Pelayanan Publik di Desa Nagarapageuh Kecamatan Panawangan Kabupaten Ciamis (Studi Tentang Pelayanan Surat Keterangan Tidak Mampu)." Moderat: Jurnal Ilmiah Ilmu Pemerintahan 4(1):107-25.

Hartati, Pahrudin HM, dan Elita Rahmi. 2020. "Political Law's Reconstruction of Village Apparatus To Realize Independent Village in Indonesia.” Journal of Government and Civil Society 4(2):145-58.

HM, Pahrudin. 2019. "The role of the Merangin regency government through welfare policy in the globalization era."The Journal of Society and Media 3(2):216-36.

HM, Pahrudin. 2020. Globalisasi dan Kebijakan Publik: Kajian Seputar Peranan Pemerintah Mewujudkan Kesejahteraan di Tengah Dunia Tak Bersekat. Jakarta: Kencana Prenada Media Group.

HM, Pahrudin dan Firdaus. 2020. "“Pilkada dan Kesejahteraan Masyarakat: Studi Kebijakan Pembangunan di Provinsi Jambi Pasca Pemilihan Gubernur 2015."” Tajdid: Jurnal Ilmu Ushuluddin 19(2):214-42.

Ismiyarto, Sri Suwitri. 2016. “'Study of Implementation village apparatus training in West Kalimantan Province." Innovation in Regional Public Service for Sustainability (ICPM 2016) 111-12.

Kisman, Zulfukar Aytac dan Izzet Tasar. 2014. "“The Key Element of Local Development."' Procedia Economics and Finance 15:1689-96.

Kurnia, Ujang Endi dan Ni Wayan Widhiasthini. 2021. “"Evaluasi Kebijakan Padat Karya Tunai Pada Pengelolaan Dana Desa Dalam Pemberdayaan Masyarakat Desa."' Jurnal Ilmiah Muqoddimah: Jurnal Ilmu Sosial, Politik dan Humaniora 5(1):148-61.

Mirnawati. 2019. “'Capacity Building Organisasi (Studi Pada Kelurahan Imopuro Kecmatan Metro Kota Metro)."' Jurnal Tapis: Jurnal Teropong Aspirasi Politik Islam 15(3):51-67.

Nak-ai, Worayuth, Temsirikulchia Lakkhana, Kinipat Nontapattamadul, dan Uthaithip Jia. 2018. “Community public policy process for solving cadmium contamination problems in the environment: a case study of Mae Sod District, Tak Province." Kasetsart Journal of Social Sciences 39:5966.

Nugroho, Setyo. 2014. “'Pengembangan kapasitas aparatur pemerintah desa dalam upaya mewujudkan good governance." Jurnal Administrasi Publik (JAP) 
2(8):1010-15.

Rosawaningsih, Nila. 2018. “"Kebijakan Pengelolaan Ruang Terbuka Hijau (RTH) Taman Flora Surabaya."” The Journal of Society and Medi 1(1):68-85.

Sahi, Nirmala Afrianty. 2018. “"Peningkatan kualitas perangkat desa guna pemantapan pelaksanaan pembangunan di Gorontalo."” Gorontalo Journal of Public Administration Studies 1(1):33-46.

Shakinah, Gita Asri Al. 2019. "Analisis penghambat kinerja aparatur Desa Batukarut Kecamatan Arjasari Kabupaten Bandung." Hal. 1178-83 in Proceeding FRIMA-2019.

Sharma, Chanchal Kumar. 2015. "'Reimagining federalism in india: exploring the frontiers of collaborative federal architecture." Asia-Pacific Social Science Review 15(1):1-25.

Syaifullah, M. 2017. “Understanding of village apparatus on implementation accounting villages." International Journal of Science and Research (IJSR) 6(8):1168-74.

Wahyudi, Agus, Sucipto Ngumar, dan Bambang Suryono. 2019. “"Faktor-Faktor yang Mempengaruhi Kinerja Manajerial Perangkat Desa (Studi pada Perangkat Desa di Kabupaten Sumbawa)." Akuntansi Dewantara 3(2):129-48.

Wahyudi, Andi, Dewi Sartika, Fani Heru Wismono, Lany Erianda Ramdani, Lia Rosliana, Mayahati Kusumaningrum, dan Siti Zakiyah. 2016. Peningkatan Kapasitas Desa. Samarinda: PKP2A III LAN.

Wikowski, Jaroslaw dan Maja Kiba-Janiak. 2014. “"The Role of Local Governments in The Development City Logistics." Procedia-Social and Behavioral Sciences 125:373-85. 